\title{
ROMANIAN HUMANISM IN THE PHILOSOPHICAL VISION OF CONSTANTIN MICU STAVILA
}

\author{
Frăguța Zaharia ${ }^{1}$
}

\begin{abstract}
The present European context challenges us to approach the issues of Romanian dignity, humanity and humanism. The purpose of this essay is to emphasize the interpretative and explanatory dimensions of Constantin Micu Stavila's philosophical thinking focused on the meaning of life and the human destiny, no less on the significance of the Christian personalism that the Romanian-French philosopher has cultivated it. Some questions arise: What is the role of philosophy and religion in understanding the meaning of life? How do we have to consider the human being and by especially the characteristics defining the Human within the Romanian culture? Trying to provide an honest, coherent and enlightening response, the paper is organized into two parts: 1 . The mission of Romanian philosophy - attempting to demonstrate that the Romanian culture is integrating itself in the world-wide one seeing that there is an intimate complementarity of philosophy and religion; and 2. Romanian cultural messianism - developing an interpretation of the Romanian folklore according to the topic of the paper.
\end{abstract}

UDC Classification: 13; DOI: http://dx.doi.org/10.12955/cbup.v5.1044

Keywords: Constantin Micu Stavila, Romanian humanism, dignity, (the) Human

\section{Introduction}

Too little known in the present Romanian philosophical field, Constantin Micu Stavila (1914-2003) was a PhD Professor at the Faculties of Philosophy and Theology in Bucharest (1942-1947). Since 1969 he settled in France where he continued his philosophical activity. We briefly mention some details of his activity related to the French culture and area: between 1970 and 1975, he was a cultural counselor at the Society of French Protestantism, and he taught General Philosophy at the Faculty of Protestant Theology in Paris. He organized the well-known Round-Tables of the American Cultural Centre in cooperation with Paul Ricoeur, Gabriel Marcel, Jean Brun, André Dumas, Octavian Vuia, Pierre Emmanuel, Jacques Ellul, and Hans-Georg Gadamer. He was a member of the Philosophy Committee at the National Centre of Scientific Research (1975-1980). During his life Constantin Micu Stavila published over 25 books in the fields of philosophy, history, ethics, and social culture.

\section{The mission of the Romanian philosophy}

We approach the issues of Romanian dignity, humanity and humanism in the vision of Constantin Micu Stavila using his anthumous and posthumous works published in Romania and abroad, in France, USA, Germany, Italy, and no less his manuscripts of Paris and Bucharest known as "Constantin Micu Stavila in Ștefan Delureanu Fund" including 9.238 pages as well as tapes and rolls.

Usually unnoticed, the difference between the state of a people and that of a nation forces the researcher studying the contemporary social phenomenon to accept and follow it. What do we mean by the fact that people tend to assert themselves as nations? Beyond of "undertaking a missionary vision of creation, people want to "prove freedom and a specific life attitude" (Micu Stavila, 1945a, p.71). We could define the nation as a social community having the conscience of its role in the world and the people as a simple community with the same language, religion and history, on the same territory, but lacking "self-consciousness, lacking the consciousness of the specific mission it would have to fulfil in this world" (Gusti, 1935/1946). Thus, we shall never face a nation as long as communities merely exist, without being enlivened by a vital passion coming from within, "without feeling the vibration of the consciousness of a nation and its mission" (Micu Stavila, 1945a, p.72). All the peoples have a destiny in creation, but we can call nations only those which succeed in representing something in the end, in understanding their destiny, in taking an active part and consciously working. In other words, only those who ignore the material, transitory interests and become aware of their own existence, of what is longlasting and permanent in them. Consequently, knowing your destiny would be directly involved in the "act by which people would become aware of one another, an act of probing their specific individuality, their spiritual essence" (Micu Stavila, 1945a, p.75). For a people to get to know its destiny it is necessary that endowed human-beings should have the availability and intelligence to read the best hidden and unreached depths of his soul, but also to be able to manifest itself as a nation. This actually means, as a whole, a body enlivened by a single will and a common faith, the only ones which could give a people

\footnotetext{
${ }^{1}$ PhD Student, „Alexandru Ioan Cuza” University of Iași, Romania, fragizaha@yahoo.com
} 
an authentic and personal affirmation of its features. People are free by moving toward a nation status and succeeding to understand what is its own and genuine. Knowing yourself means being free but also going beyond your own limits and accomplishing yourself. Thus, the individual or the people acquire, at the same time with self-consciousness, a dynamic element, a principle of progress and freedom which is precisely the awareness of human dignity. Thus, particular nations change themselves into creators of culture.

Having a clear idea about the features they had been endowed with, the nations consciously take part in the unveiling of their destiny, behaving like beings who know what to want. Starting from this moment only, that nation becomes a culture creator. The human existence is characterized by the fact that it is part of the cultural, spiritual world. None society was deprived of arts or, even more, of religion. Everywhere man undertakes a social activity we notice the need for a spiritual manifestation which is intertwined. The culture is a primordial datum of human life, but the possibility to develop an original, strong and long-lasting culture is possible only for a people that experience a deep messianic feeling, a creative will. Hence, to reaching a cultural achievement remains an obligation for any people; it is a condition of living, a vital imperative. What does it mean to put one people's desire for creation under favorable conditions? It means to make it become the constant aspiration of the national consciousness, to determine it to identify oneself with the consciousness of a people's mission, to be part of the nation's being. Lacking the nation consciousness, a people can't create, they lose their identity and weakens the historical being, consequently being prone to extinction. In order to settle and maintain culture, a high consciousness of the nation's mission and human dignity is required. All the energy of a nation keeps its sources in the spiritual resources.

Constantin Micu Stavila believes that the most important function of any people is to make an analysis of the conditions and premises of a spiritual life of the superior human type and to be a forerunner and a revealing actor for the self-consciousness of the nation. For the universal thinking, the highest preoccupation is to discover the hidden premises of man's spiritual existence of all times and to establish the meaning of his presence in the world. Consequently, for the Romanian philosophy, this preoccupation should be associated to that of seeing if the spiritual premises of the Romanian have a value of universality, if they express the true and constant essence of the man or if they are not only precarious or relative forms of consciousness. Following this path and undertaking such a task, the Romanian philosophy of the future could fulfill two desiderata: to go on the line of the Romanian reality and at the same time, to be in accordance with the special concern of time, namely that of seeing the man as the capital issue of existence.

Concerned with the mission of philosophy, Micu Stavila shows that there is a mistake to drawing slashing lines between religion and philosophy, between science and faith. Science is not content with the mere quantitative gathering of facts, but it searches to explain them, to uncover their reasoning or meaning by means of hypotheses, which are even the result of an act of faith, a leap of reason beyond its limits. The parallelism between philosophy and religion is seen in the fact that religion is interested about the purpose and value of existence, and both of them try to offer answers to human being as regards life, stimulating the aspiration toward perfection and ideal.

The quintessence of the deepest philosophical issue of all times remains the rapport between knowledge and existence, on one side and knowledge and redemption, on the other. The first questions man has ever asked himself, for the practice of his knowledgeable activity, was that of knowledge value, of its purpose. But philosophy as science of universality should not leave anything without being studied. Some metaphysical systems - not deprived of mysticism, in agreement with the religious allegory of falling into temptation - pretend that humans, by rebelling, have been taken apart from divinity, thus losing the right to everlasting happiness. If there is a way to have a relationship with divinity, as Micu Stavila states, than it can only be that of the intellect. Without the intellect, none creative activity of spiritual values is possible, nor any means of transcending nature and communicating to pure spirituality, to God. Christianity admits the existence of $\sin$ in the world, but it does not attribute the exercise of knowledge to it. The light in which sin is presented by Jesus in his preaches is similar to a greater extent to instinct, to non-reflection, to a blind, non-rational acceptance of life. Getting freed from sin is nothing else but getting free from instinct, by no means from reason. Jesus demands to "renouncing oneself," not rationality - in the contracted form, rationality means individuality. As an instrument of individual conservation, it serves more to the fight for spiritual survival, in other words, for immortality and not 
for physical existence, it tends not only to preserve but also to expand and perfect individuality. Evil is the blind, selfish, brutal existence, lacking knowledge, while good represents the broken existence, enlightened, ennobled and overcome by knowledge.

Between real and ideal, man feels the need to unify these two terms. Revealing for the over-sensitive dimension, ideal to existence, reason will uselessly be denounced as a knowledge function opposed to the spiritual synthesis of faith. Faith separates from reason in the same way as theology separates from philosophy, more precisely: not by the ideas they postulate as the highest ideal to be reached, but by means it conveys in order to reach it. Reason is limited to indicating the existence of the over-sensitivity, the divine, while faith demands getting close to the divine by means of love. Reason can contradict the necessity to love divinity as much or as less as faith can exclude the necessity to understand and rationally comprehend. We can love only what we know and if it seems we love before knowing, that is because the "zeal for knowledge flies more quickly than that of love and it indicates us the reasons for love even earlier than we could have realized it clearly. The love for divinity itself cannot be excluded from this rule and it could have never happened on the absence of some knowledge about the divine being, be it called revelation or in another way" (Micu Stavila, 1943, p.23). Love is the most direct corollary of knowledge, what it does, is only to end a circuit the latter opens. It is the essence of love to overcome any duality and conflict. The consciousness of this fact precedes and justifies the superior, unifying zeal of love. After all, love, as well as knowledge, means being fond of something. In order to know that this something exists, knowledge should have been given from the beginning. This is the reason why faith in God cannot be separated neither by love for, nor by his knowledge. In reality, the scientific and religion fields are co-extensive: knowledge precedes and determines faith, and the other way around is also possible.

\section{Application: on the Romanian humanism}

By humanism, we usually understand the movement focused on the idea of human being as a central one in the Universe, manifested in Renaissance against the theocentrical spirituality from the Middle Ages. The blame casted on the Christian civilization for having disregarded the dignity and the value of the human being is greatly justified by the fact that it uses the thesis which states that the essence of man is touched by evil as a consequence of disrespected divine order. Christianity is responsible for getting down the human being from the pedestal the Greek and Roman civilizations put him on. The latter not only gives the human-being the greatest importance in the world, but also considers him able to share the use of reason together with the gods; man becoming the carrier of political, aesthetical and ethical values. Under the influence of the original sin, the two fundamental human features - ability to learn and to work - are qualified by Christianity as punishment and deficiency. However, the progress made in all fields will give back to the human being the trust in the superiority and dignity of the spirit. In Oratio de hominis dignitate, Pico della Mirandola states that the human-being is perfectible, free to create his own destiny using reason, capable of imposing rules on reality and enrich on spiritual level. The man, the only owner of the spirit in the world, regains the trust in the spirit in contradiction to Rousseau's naturalism, Darwin's evolution, Haeckel's biological monism and Marx's historical materialism that canceled any difference between human beings and other beings.

Still, beside the thesis of the original sin, Christianity also comes with the idea of "rebirth, baptism and repentance, together with the dynamic idea of a new world and a new human-being, once Christ was born, a world free of sin, capable to get accomplished and progress, a man reconciled with Divinity" (Micu Stavila, 1945a, p.4). In fact, the conflict between Christianity and the humanist elements of GreekRoman culture is fortuitous: it does not exclude, but it involves the trust in man's dignity. In Europe, the rebirth of humanism is nothing but the rebirth of man in the new Christian spirit. As a novelty, Christianity introduces the concept of transcendent, postulating both an ideal world, essentially and radically different from the limits of the sensitive world, and the idea of Divinity outside the human world, not present and mainly incorporeal. The human being can have access to divinity by means of the ideal, the invisible part which is the basis of spiritual deeds and leads him to his self-accomplishment and frees him from the impulses and desires of the physical world. The antagonism man-world can be felt with such an intensity in the consciousness of the peoples who embraced Christianity and as the Romanian folk lyrics confess: "Should the world be of paper / I would set it on fire when angry / Should the world be a branch, / I would cut it with an axe" (Jarnik \& Bârseanu, p.202). 
How do we see the Romanian humanism in the historical dispute between Christianity and Classicism and what origin could it have? Together with the philosopher Constantin Micu Stavila, we appreciate that due to the old age of the Thracic culture and the parallel to the Greek-Roman culture, the Romanian humanism is included in the classical sphere. And the twist of the situation operated by Christianity (of which the Romanian people is fully aware) in the religious representations of humanity by introducing the idea of an imperfect world, the conscious - world dualism and antagonism, the concept of human dignity has a Christian origin. The scientific proofs establish not only the existence of a relationship between the main centers in antiquity - Greek and Roman on one side and Thracian on the other - but there is also the possibility of a descent in our classical culture in the part of the latter. In Die Geburt der Tragödie aus dem Geiste der Musik (1872) Nietzsche derives the birth of music and the tragedy from Dionysus's cult, the Greek deity borrowed from the Thracians. The latter also had the first impulse for poetry, in Orpheus. The German researcher specialized in mythology Hermann Güntert insists on the descent of the myth of the savior god of the world from the Thracian religious concept, on its mediating role between Iran, India and Europe in his work entitled Der arische Weltkönig und Heiland (1923). Analysing the relations between the German and the Thracian - in Walhall. Studien über germanischen Jenseitsglauben (1913) and in Die Überlieferungen vom Gotte Balder (1920) -, Gustav Neckel sees the possibility of deriving old religious representations of the Thracian gods. These statements are also supported by O. Weinreich in Neue Urkunden zur Sarapis-Religion (1919). Thus, the result of the scientific research brings to light the depth of the relationship between the old elements in our Thracian culture and that Roman-Greek one, but also the contribution of the former in elaborating the classical miracle. Some interesting suggestions regarding the active existence of the relationships between our Thracian culture and the Greek-Roman culture can also be found in our historical literature, underlining the role of a matrix played by the former. Nicolae Densușianu, in Dacia preistorică, places the cradle of the Indo-European culture in Dacia, and gives to the Getae culture the role of a constitutive element for the Greek-Roman culture.

The results of the contemporary history research give arguments for the old age of spirituality, implicitly of Romanian humanism, based on the idea that any culture is the basis of the original spirituality and it is fulfilled by the conception about the man and his role in the world. If we understand by humanism the totality of the representations a people might have about the superior human type, we further aim to present in detail the specific way in which the human being is seen and how it is pictured in the Romanian culture, more precisely, in the Romanian folklore. We let the people - by means of the permanent and universal elements of the self-consciousness reflected in myths, proverbs, ballads, legends - to give an answer to the following question: How does the Romanian man perceive and what features give him the quality of a Human Being so as to account for his dignity and humanity? One condition for discovering the truth, scientific and philosophical knowledge and progress usually is originality and personal inventive action, in the philosophy of culture it is needed to go beyond subjectivity and identify itself to the over-individual reality of the national ethos. In the Romanian vision, the human being, a different being in the natural world ranking is endowed with moral and intellectual special traits. "The Romanian does not give the human-being another role but to exteriorize his own humanity and to behave in the world with all dignity, moral eminence of a spirit which loves justice, beauty, love and truth and goodness" (Jarnik \& Bârseanu, 1968, p.8). Man's right to get above the other creatures, to aspire at the cosmic hegemony, consciousness of the human spirit's responsibility and last but not least, the special message of goodness can be seen from the folklore lyrics: "God, let me be a rainbow/ To go high up to your sky / As I mean no harm", but also in the Romanian's refusal to be part of the general pessimism which refers to the evil essence of man. To live according to the spirit, not the natural instincts, remains the religious ideal of the Romanian.

Traits of moral consciousness such as kindness, love, justice and mercy are frequently sung in ballads and folk songs and in the name of the spiritual values, the Romanian rebels against the ignorant, conformist and inert nature of things: "Fight, you heart, / Don't stay as a bull in the shed. / Go on, fight / Do not stay like the bull in the pond" (Bologa, 1936, p.186). The rebellion against the conservation instinct, the routine and usual things sends to the proclamation of progressive, dynamic, fighting ethics and a life lived dangerously which considers the need for moral perfection above any other material comfort. This consciousness of necessary progress, the superiority of the ideal on the real, of what it could be and should be on what it is, sometimes is rendered in expressions with a deep meaning: "A 
man is sad / when his bull goes for a heifer / and his daughters after servants" (Onișor, 1892, p.44). In other words, that imperative on human perfectibility which means the aspiration to getting noble, overcome the existence and not only simply preserving it or even degrading it. The following lyrics also speak about the sense of hierarchy which guarantees perfectibility and losing it is seen as a catastrophe as it influences existence in its mere reason of being: "It is the end of time/ The end of Earth / when the son strikes the father / and the daughter strikes the mother / younger brother hits the older / Younger sister in the older" (Bologa, 1937, p.62). The respect for the idea of "good family" and the sense of hierarchy are an expression of the conviction that life should bring more, not only be lived. Human beings aim to accomplish values and purposes at maximum, due to the qualities of a superior development, imposing himself as a noble man due to his personality and intelligence. To be of good family actually means to fulfill the maximum requirements of human personality. "Say dear to your mum / That I don't need. / Straws and yellow flowers in the windows / Yellow and white flowers, / I don't need any of your family / Yellow, white flowers and wormseed, / I don't need any of your kin" (Bârlea, 1968, p.108).

The moral beauty of the soul, not the material one of the body is seen as important as expressed in the lyrics: "Handsome is not he who lasts / But handsome is he who suits well.", and this "suits well" refers to what suits good deeds, what entails goodness in life, there is always a moral attitude of the spirit which lies above the physical beauty. As it is right coming from: "Even the ugly looks well / When he walks as it is right" underlines the idea that beauty and ugliness are decided upon moral and not material criteria. As in the conception of the Romanian people, beauty is only a manifestation of goodness, and ugliness the deviation from the condition of humanity - the inherent obligation of man to be consequent to the spiritual human condition, to keep up to the moral demands of social life based on meritocracy and hierarchy. "Man is not ugly for being unpleasant / But he is ugly for being out of order" (Bârlea, 1968, p.306). Deprived of order, of a family, he will also be deprived of the element which characterizes the real human personality, only if he aspires to a continuous development of the spiritual possibilities, only then, a human being will remain a human being. Avoiding the moral desideratum of trying to be better than he is, it deprives the human being from the noblesse which is characteristic to his being. "It is noble that who gets better than himself, that who is capable of going over the limits of his being, continuously searching to be something different and even more than he already is. The proud stillness in self-content feeling is a disqualifying attitude for a human being" (Micu Stavila, 1943, p.12).

The movement toward an area of non-determination, unifying real and possible, usual and ideal, what is and what it should be, is part of the human essence. Only the human being has science, art, religion and morals and can look beyond himself. He feels there is something beyond being and having, something which goes beyond any limit and attribute of existence, something beyond which is pure and virtually to be touched by the nobility of the human spirit and which gives it the real moral beauty and unique presence in the world. Being aware of the imperative of trying to become better, the folk poet blames self-sufficiency, being interested only in the current day, ignoring the ideal and what the individual might become. Avoiding making an effort to discover a new self, in the view of the Romanian people it equals evil, sin; or as Micu Stavila stated: "a selfish appearance of being against the will to self-improvement" (1943, p.13). The Romanian man / woman knows too well that life should not only be lived, but making more noble by sacrificing the current limits of the human being. The imperative prescribed to any individual as a rule of moral behavior by Goethe in Selige Sehnsucht is deeply rooted in his consciousness: "Stirb und werde!" ("Die and become!"). The Romanian people clearly know that ideally, making life more valuable requires an ethics of giving up and away, of sacrifice and that is why they despise a life dedicated to utility and pleasure. They will always prefer to fulfill the essential condition of their spiritual dignity, namely the ability to be a denier of life, that "der Neinsagenkönnen" according to Max Scheler in his 1928 Die Stellung des Menschen im Kosmos. The moral ideal of the Romanian lies in looking for danger, hardship, next to giving up frivolous pleasures. Tudor Arghezi, in Psalms, underlines the value of pain and effort against philistinism: „In my bowl, as in my thought / I have got used the poisonous taste./ I bathe in ice and I sleep on rock./ Where there is darkness I make sparks,/ Where there is silence I shake the cuffs/ I bring down the door with the chains./ When I am on the peak/ I'm searching for danger./ I choose the narrow path to go ahead/ Carrying the whole mountain on my back" (Arghezi, 1960), in agreement with an anonymous folk song: "The man who is a man / Does not sleep in bed at night,/ Only on dry ground." (Bologa, 1936, p.99); or: "The young man, who 
is a young man? He sleeps on bare ground." (Jarnik \& Bârseanu, 1968, p.382) We cannot speak by far of any inability to adapt to the civilized conditions or primitivism, but about a scale of values and ideals. Keeping awake the competitive force of the spirit gives pride to the man who arduously thrives to be a Man. Without the power to say no to the hedonistic demands, the man loses his independence and gains distance to the world, finally reaching freedom. By practicing it - a guarantee of getting above the requirements of necessity - is reached real human dignity. To be free means to appeal as little as possible to the pleasure given by things; an austere life in which the moral and soul demands for knowledge, goodness, beauty, love, in the vision of our people acquires the sign of superiority. The way to perfection requires generosity but also the knowledge to take the best out of himself using the fulfilling power of love. "That my dear brought to me / Sweet milk in bead / And we both ate / And there was still some left / For a bird to eat as well."

The preference for beauty, the desire to make the useful things pleasant, to give them a meaning, value, spiritual significance is one of the most important features of the Romanian. The tendency to garnish things, to give them a festive look, to make them suitable for contemplation, not only to be useful, that aesthetic drive has been long mentioned as a feature of Romanian spirituality. A constant effort to increase beauty in detail and to change their look into an aesthetic way is nothing but the expression of good will and the generous drive of the spirit scattered around things aiming to enrich and make them much nobler following the model of inner perfection. The one who searches beauty will know how to avoid evil, choosing goodness. "Oh, my God, I expect nothing / But merely what is right and good." (Jarnik \& Bârseanu, 1968, p.199) Because the sense of beauty cannot be detached from the power of love and goodness of the heart, the Romanian will create an ideal world of the art to adjust reality. The aesthetic emotion, a medicine against evil, but also a principle of adjusting existence, might train the soul to serenity, giving the man the power to stand any blow. "God, give only good to those who envy / And me to endure what is rightful for me. / And give them good chance / And to endure what chance is. / Give them as much good as they might want / And I endure as much as I can." (Bârlea, 1968, p.168)

\section{Conclusion}

According to Constantin Micu Stavila, we can conclude that the inner features examined above are included in the picture of the Romanian ideal man. Self-control, drive for perfection, an ethics of generosity, modesty, sacrifice and giving away, the cult of goodness, the sense of beauty and the power of love, all under one name which represents Romanian humanity. The key of the Romanian humanism lies in this original attitude - kindness - which is to be understood in terms of the relation between the notions of human being and Romanian, on the one hand, and the word Human as describing the moral endeavor, on the other hand. Still, Romanian humanism is not reduced only to goodness it corresponds to moral features of the human spirit and it also has an intellectual function of knowledge. The Romanian creates a link between the exercise of knowledge and that of moral power. Reason plays a part determined by his inner life as well as by his acts; for example, when he expresses his feelings, he speaks with the whole language of reason. Decency and shame explain the moderating interference of the intellect on feelings. The predilection of the Romanian for a reason goes so far, that its absence is seen as cause for suffering and obstacle which cannot be surpassed in the way to love. "Why are you crying, my sister? / How could I not cry / As I married a dull man" (Jarnik \& Bârseanu, 1968, p.171) or: "I liked you for nothing / If you had no mind" (Bibicescu, 1893, p.74). This application gives all the reasons to appreciate the Romanian people as inheriting the noble traditions of the Gets and Thracians, and keeper of the Christian spiritual tradition, with a high moral value of life which should be known and positively included in the cultural heritage. As an active, insurrectional, and creative being, a man / woman is able to change the reality and to shape it after his / her own pattern.

\section{References}

Arghezi, T. (1960). Cuvinte potrivite: Psalmi [Fitted Words: Psalms]. Bucharest: Literature Publishing House. (Original work published 1927)

Bârlea, I. (1968). Literatura populară din Maramureș [Folk Literature of Maramureș]. Bucharest: Literature Publishing

House.

Bibicescu, I.G. (1893). Poezii populare din Translivania [Folk Poems of Transylvania]. Bucharest: State Printing House.

Bologa, V. (1936). Poezii poporale din Ardeal [Folk Poems of Transylvania]. Sibiu: (n.p.).

Bologa, V. (1937). Colinde poporale din Ardeal [Folk Carols of Transylvania]. Sibiu: (n.p.).

Densușianu, N. (2002). Dacia preistorică [Prehistoric Dacia]. Bucharest: Archetype Press. (Original work published 1913) 
Güntert, H. (1923). Der arische Weltkönig und Heiland. Halle/Soale: M. Niemeyer.

Gusti, D. (1935/1946). Sociologia militans. Bucharest: Mihai I King Foundation Press.

Jarnik, J. U., \& Bârseanu, A. (1968). Doine și strigături din Ardeal [Doinas and Screams of Transylvania]. Bucharest: Romanian Academy Publishing House.

Micu Stavila, C. (1943). Problema umanismului din punct de vedere al spiritualității românești [The Issue of Humanism from the Point of View of Romanian Spirituality]. Bucharest: University Printing House.

Micu Stavila, C. (1945a). Existență şi adevăr [Existence and Truth]. Bucharest: Bukovina Printing House.

Micu Stavila, C. (1945). Origina creștină a problematicei filosofice moderne [The Christian Origin of the Modern Philosophical Problem]. Bucharest: Church Books Printing House.

Neckel, G. (1913). Walhall. Studien über germanischen Jenseitsglauben. Dortmund: F. W. Ruhfus.

Neckel, G. (1920). Die Überlieferungen vom Gotte Balder. Dortmund: F.W. Ruhfus.

Nietzsche, Fr. (1872). Die Geburt der Tragödie aus dem Geiste der Musik. Leipzig: E.W. Fritzsch.

Onişor, V. (1892). Doine și strigături din Ardeal [Doinas and Screams of Transylvania]. Iași: Șaraga Brothers Publishers.

Scheler, M. F. (1928). Die Stellung des Menschen im Kosmos. Darmstadt: Otto Reichl Verlag.

Weinreich, O. (1919). Neue Urkunden zur Sarapis-Religion. Tübingen: J.C.B Mohr (Paul Siebeck). 